\title{
EXTERNAL GENITAL TUMORS IN WOMEN: ROLE OF DIFFERENTIATION, LOCALIZATION AND HISTOLOGICAL TYPES FOR PREDICTING LONG-TERM SURVIVAL VALUE
}

\section{INTRODUCTION}

External genital cancer ranks fourth after cervical cancer, uterine cancer and ovarian cancer in terms of the indicator of incidence of female genitalia tumors $[1,4]$.

Standardized incidence rate of vulvar cancer varies between $1.3-1.4$ cases per 100,000 in Ukraine. Invasive squamous cell vulvar cancer is $90.0 \%$ of all vulvar malignant tumors and 1.0 $2.0 \%$ of malignant epithelial tumors [3]. It should be noted that vulvar cancer is a disease of elderly and old women, $80.0 \%$ of invasive vulvar cancer is diagnosed in women older than 55 years, the average age of patients is $65-68$ years, whereas the peak of the incidence is 75 years $[5,6,8]$.

In spite of its visual and manual diagnostic availability, external genital cancer is one of the most intractable malignant tumors of the reproductive system of a woman [10, 12, 13, 17].

On the one hand, this is due to the features of blood supply, innervation and lymph influx, as well as the topographic proximity of adjacent organs; on the other hand - to a high psychosexual and physiological significance of female external genitalia for normal life [19, 21]. External genital cancer is characterized by high levels of disability, a significant deterioration in the quality of life, limitation of vital activity and a sharp decline in the potential of social adaptation and integration of women [23].

According to the literature, there is a significant variability of the factors associated with the prediction, mortality and survival in patients with vulvar cancer $[15,16,20,25]$. The etiological factors of this disease have not been fully established, when all existing diagnostic and treatment methods require improvement $[9,24,26]$.

Purpose of the study was to investigate the role of the tumor degree, localization and histological type of tumor at the level of long-term survival by 25-year retrospective observation in women with external genital cancer.

\section{MATERIALS AND METHODS}

The basis of the work is a 25-year retrospective observation (557 medical records of the patients treated in National Cancer Institute, Kyiv, from 1993 to 2018). The average age of patients was $62.3 \pm$ 13.2 years, with a distribution from 18 to 90 years.
Histological and morphological research had been carried out on the basis of paraffin blocks of biopsy made before the start of therapy. Histological typing was performed by use of routine (staining with hematoxylin and eosin) and immunohistochemical research. The resulting biopsy material was fixed in $10 \%$ buffered formalin with $\mathrm{pH} 7.4$ to be sealed in paraffin with Histos-5 tissue processing machine (Milestone, Italy). They used paraffin blocks to make microscopic sections with a thickness of $5 \mu \mathrm{m}$ by Microm HM325 (Thermo Scientific, Germany) microtome. The sections had been stained with hematoxylin and eosin for a general tumor assessment.

The primary objective of research consisted in the study of long-term survival value. The risk of adverse events was assessed taking into account the odds ratio (OR) and the reliability criterion for OR. The long-term survival value had been assessed using Kaplan-Meier analysis with the calculation of log-rank test and relative risk indicator between survival curves - OR, evaluation of the indicators - medians of survival, exponential medians for the duration of the case and frequencies of cancer mortality. Differences were considered statistically significant at $\mathrm{p}<0.05$.

\section{RESULTS OF THE STUDY}

A long-term survival value in patients with external genital tumors over 25-years of observation was $47.8 \%$ (from 0 to 36 years); average survival rate was $6.0 \pm 4.48$ years (Figure 1 ).

According to the degree of primary tumor, an even distribution between G3 tumor degree (229 patients, 41.1\%) and G2 tumor degree (220 patients, $39.5 \%$ ) had been established, G3 had been established in $19.4 \%$ of cases (108 patients) (Figure 2).

Cancer mortality level in patients with external genital tumors depending on primary tumor degree during a 25-year retrospective observation is presented in Table 1.

Mortality progressively increased by $27.3 \%$ from $\mathrm{G} 1$ to $\mathrm{G} 2$ tumor degree and by $10.8 \%$ from G2 to G3 tumor degree (Table 2). OR increased in total mortality during transition from G1 (OR 1.0) to G2 (OR 1.80), from G2 to G3 (OR 2.12), cumulative OR $(1.72,95 \%$ confidence interval (CI) 1.322.25), generalized OR (1.642, 95\% Cl 1.29-2.08) have been proved (Table 2 ). 


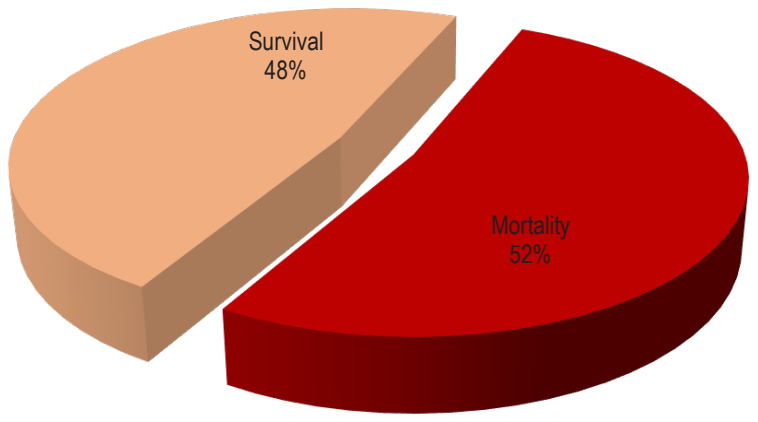

Figure 1. Long-term survival value in patients with external genital cancer for the period of 1991-2018 years by retrospective observation

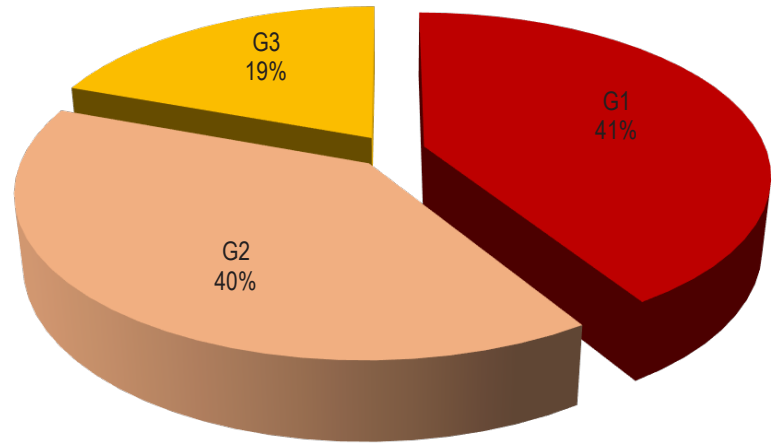

Figure 2. Distribution of patients by primary tumor degree

Table 1. Cancer mortality in patients with external genital tumors depending on primary tumor degree during a 25 -year retrospective observation

\begin{tabular}{|c|c|c|}
\hline Degree of differentiation & $\mathrm{n}$ & $\%$ \\
\hline High & 108 & 19.4 \\
\hline Intermediate & 220 & 39.5 \\
\hline Low & 229 & 41.1 \\
\hline
\end{tabular}

Table 2. Relative probability and OR of cancer mortality in patients with external genital tumors during a 25-year retrospective observation, depending on tumor degree of primary tumor

\begin{tabular}{|c|c|c|c|}
\hline Tumor degree & OR & $\begin{array}{c}\text { Cumulative 0R } \\
\text { (proportional } \\
\text { odds model) }[95 \% \mathrm{Cl}]\end{array}$ & $\begin{array}{c}\text { Generalized OR } \\
\text { (Agresti's alpha) } \\
{[95 \% \mathrm{Cl}]}\end{array}$ \\
\hline High & 1.0 & & 1.72 \\
\hline Intermediate & 1.80 & {$[1.32-2.25]$} & 1.642 \\
\hline Low & 2.12 & & {$[1.29-2.08]$} \\
\hline
\end{tabular}

Multiple Kaplan-Meier survival analysis showed that the overall level of 25-year survival at retrospective observation was $45.0 \%$ for $\mathrm{G} 1$, 31.0\% for G2, $26.0 \%$ for $\mathrm{G} 3$. At the same time, the $\chi^{2}$ logistic regression criterion was $4.72, p<0.05$.

Histologically squamous cell cancer (83.3\%) dominated in the retrospective group; melanoma was verified in $8.2 \%$ of patients, carcinoma in $6.1 \%$ of patients, sarcoma in $2.0 \%$ of patients. Undifferentiated forms of cancer had been found in 2 cases (0.4\%) (Table 3 ).

A similar pattern is also established for assessing OR of overall mortality and estimating the linear trend. It should be noted that all morphological forms of external genital cancer are unfavorable and characterized by high mortality rate - the proba-
Table 3. Distribution of patients of retrospective group by the morphological characteristics of primary tumor

\begin{tabular}{|c|c|c|}
\hline Morphological type & $\mathbf{n}$ & $\%$ \\
\hline Squamous cell cancer: & 464 & $83.3 \%$ \\
\hline • keratinized squamous cell cancer & 160 & $28.7 \%$ \\
\hline non-keratinized squamous cell cancer & 41 & $7.4 \%$ \\
\hline basal cell carcinoma & 5 & $0.9 \%$ \\
\hline Carcinoma: & 34 & $6.1 \%$ \\
\hline - adenocarcinoma & 14 & $2.5 \%$ \\
\hline Melanoma & 46 & $8.2 \%$ \\
\hline Sarcoma: & 11 & $2.0 \%$ \\
\hline •liposarcoma & 1 & $0.2 \%$ \\
\hline rhabdomyosarcoma & 3 & $0.6 \%$ \\
\hline - angiosarcoma & 2 & $0.4 \%$ \\
• fibrosarcoma & 2 & $0.4 \%$ \\
\hline Undifferentiated cancer & 2 & $0.4 \%$ \\
\hline
\end{tabular}

ble difference in the mortality rate by cumulative OR $(0.77,95 \%$ $\mathrm{Cl} 0.58-1.01)$ and generalized OR $(0,86,95 \% \mathrm{Cl} 0.69-1.07)$ had not been established.

\section{CONCLUSIONS}

1. In case of transition from high to moderate degree of differentiation the long-term survival value decreased by $27.3 \%$, in case of transition from moderate to low differentiation - reduced by $10.8 \%$.

2. The general level of 25-year survival in retrospective observation was $45.0 \%$ - for high degree of tumor differentiation, $31.0 \%$ - for moderate, $26.0 \%$ - for low degree of differentiation $(\mathrm{p}<0.05)$.

3. The highest cancer mortality rate had been proved in case of total lesion (66.7\%), as well as with lesions in several areas (80.9\%). In case of primary tumor localization in the area of labia majora, compared to the vulva tumors, the probability of cancer mortality increased by $45 \%$ (OR 1.45); whereas if localization in the area of labia majora was higher by $91 \%$ (OR 1.88); in case of location in the area of clitoris raised by $19,0 \%$ (OR $1,19)$; in lesion of several areas increased by $78.0 \%$ (OR 1.78).

4. Multiple Kaplan-Meier survival analysis showed that the area of labia minora was the most unfavorable localization, where the probability of survival in 25 -year retrospective observation was $6.0 \%$ versus $23.0 \%$, when primary tumor localized in the area of labia majora; and versus $35.0 \%$ when localized in the vulva area.

5. Depending on the morphological form of the primary tumor the highest rates of cancer mortality are verified in undifferentiated forms of the tumor (100.0\%) and for sarcoma (63.6\%). For all forms of squamous cell cancer, the cancer mortality rate was more than $50.0 \%, 53.9 \%$ for squamous cell undifferentiated cancer, $56.9 \%$ for keratinized squamous cell cancer and $56.1 \%$ for non-keratinized squamous cell cancer. Carcinoma and adenocarcinoma with a level of cancer mortality of 20.6 and $21.4 \%$ respectively were more favorable compared to the other morphological forms. 


\section{ПУХЛИНИ ТА ПЕРЕДПУХЛИННА ПАТОЛОГІЯ}

\section{REFERENCES/ЛІTЕPATУPA}

Pushkarev, V.A., Mazitov, I.M., Khusnutdinov, Sh.M., Golov, E.K "Analysis of the Clinicopathological Features of Vulvar Cancer." Medical Bulletin of Bashkortostan 9.3 (2014): 50-4.

Пушкарев, B.A.

Анализ клинико-патологических особенностей рака вульвы / В.А. Пушкарев, И.М. Мазитов, Ш.М. Хуснутдинов, Е.К. Голов //

Медицинский вестник Башкортостана. - 2014. - Том 9, № 3. - С. 50-54.

2. Nerodo, G.A., Nepomniashchaya, E.M., Nerodo, E.A.

"The Clinical Course of Vulvar Cancer in Patients of Reproductive Age." Creative

Surgery and Oncology 3 (2012): 61-6.

Неродо, Г.А.

Клиническое течение рака вульвы у больных репродуктивного возраста

/ Г.А. Неродо, Е.М. Непомнящая, Е.А. Неродо // Креативная хирургия и

онкология. - 2012. - № 3. - С. 61-66.

3. Fedorenko, Z.P., Mikhailovich, Y.Y., Gulak, L.O., et al.

Cancer in Ukraine 2016-2017. Incidence, Mortality, Performance Indicators of

the Oncological Service. Bulletin of the National Cancer Register of Ukraine No. 19 (2018): $136 p$.

Федоренко, 3.П.

Рак в Україні 2016-2017. Захворюваність, смертність, показники діяльності онкологічної служби / З.П. Федоренко, Ю.Й. Михайлович, Л.0. Гулак та ін. // Бюл. Нац. канцер-реєстру України. - 2018. - № 19. - 136 с. 4. Shalbaeva, R.S., Batyrkanova, G.K., Kamarly, Z.P., Makimbetov, E.K. "Epidemiological Aspects of Vulvar Cancer (Literature Review)."Bulletin of the Kyrgyz-Russian Slavic University 13.12 (2013): 189-193.

Шалбаева, Р.Ш.

Эпидемиологические аспекты рака вульвы (обзор литературы) / Р.Ш. Шалбаева, Г.К. Батырканова, 3.П. Камарли, Э.К. Макимбетов //

Вестник КРСУ - 2013. - Т. 13, № 12. - С. 189-193.

5. Haddad, H., Engohan-Aloghe, C., Belhaj, S., et al.

"A very misleading vulvar tumor." Ann Pathol 35.4 (2015): 368-70.
6. Alligood-Percoco, N.R., Kessler, M.S., Willis, G.

"Breast cancer metastasis to the vulva 20 years remote from initial diagnosis: A case report and literature review." Gynecol Oncol Rep 13 (2015): 33-5.

7. Perrone, G., Altomare, V.,Zagami, M., et al

"Breastlike vulvar lesion with concurrent breast cancer: a case report and critical literature review." In Vivo 23 (2009): 629-34.

8. Barlow, E.L., Kang, Y.J. Hacker, N.F., et al.

"Changing Trends in Vulvar Cancer Incidence and Mortality Rates in Australia

Since 1982." Int J Gynecol Cancer 25.9 (2015): 1683-9.

9. Fuh, K.C.

"Current management of vulvar cancer." Hematology - Oncology Clinics of

North America 26 (2012): 45.

10. Hacker, N.F., Barlow, E.L.

"Staging for vulvar cancer." Best Pract Res Clin Obstet Gynaecol 29.6 (2015):

$802-11$.

11. Go-Eun, B., Yoon, G., Yong-Jung, S., et al.

"High-grade squamous intraepithelial lesion arising adjacent to vulvar lymphangioma circumscriptum: a tertiary institutional experience." Oncotarget 7.30 (2016): 48120-9.

12. Koh, W.J., Greer, B.E., Abu-Rustum, N.R., et al.

"Vulvar Cancer, Version 1. 2017, NCCN Clinical Practice Guidelines in Oncology."

J Natl Compr Canc Netw 15.1 (2017):92-120.

13. Chokoeva, A.A., Tchemev, G., Cardoso, J.C., et al.

"Vulvar sarcomas: short guideline for histopathological recognition and clinical management. Part 1."Int J Immunopathol Pharmacol 28 (2015): 168-77.

14. Moore, D.H., Ali, S., Koh, W.J., et al.

"A phase II trial of radiation therapy and weekly cisplatin chemotherapy for

the treatment of locally advanced squamous cell carcinoma of the vulva: a gynecologic oncology group study." Gynecol Oncol 124.3 (2012): 529-33.

15 Joura, EA, Ault KA Bosch, EX, et al.

"Attribution of 12 high-risk human papillomavirus genotypes to infection and

cervical disease." Cancer Epidemiol Biomarkers Prev 23.10 (2014): 1997-2008.
16. Hay, C.M., Lachance, J.A., Lucas, F.L., et al.

"Biomarkers p 16. Human Papillomavirus and 053 Predict Recurrence and

Survival in Early Stage Squamous Cell Carcinoma of the Vulva."J Low Genit Tract Dis 20.3 (2016): 252-6.

17. Carter, J.S.

"Vulvar and vaginal cancer." Obstetrics \& Gynecology Clinics of North America 39 (2012): 213.

18. Barlow, E.L., Kanq, Y.J., Hacker, N.F., et al.

"Changing Trends in Vulvar Cancer Incidence and Mortality Rates in Australia

Since 1982." Int J Gynecol Cancer 25.9 (2015): 1683-9.

19. Cooper S.M., Madnani, N., Margesson, L.

"Reduced Risk of Squamous Cell Carcinoma With Adequate Treatment of Vulvar

Lichen Sclerosus." JAMA Dermatol 151.10 (2015): 1059-60.

20. Desouki, M.M., Chamberlain, B.K. Li, Z.

"The role of immunohistochemistry in the evaluation of gynecologic pathology

part 2: a comparative study between two academic institutes."Ann Diagn

Pathol 19.5 (2015): 296-300.

21. Chase, D.M., Lin, C.C., Craig, C.D., et al

Disparities in Vulvar Cancer Reported by the National Cancer Database: Influence of Sociodemographic Factors." Obstet Gynecol 126.4 (2015): 792-802.

22. Vyas, R., Thompson, C.L., Zargar, H., et al.

"Epidemiology of genitourinary melanoma in the United States: 1992 through

2012." J Am Acad Dermatol 75.1 (2016): 144-150.

23. Farrell, R.G., Hacker, N.F.

"Quality of life after complete lymphadenectomy for vulvar cancer: do women prefer sentinel node biopsy?" Int J Gynecol Oncol 24.4 (2014): 813-9.

24. Hill-Daniel, J., Roett, M.A.

"Genital Cancers in Women: Vulvar Cancer." FP Essent 438 (2015): 31-43.

25. Groenen, S.M., Timmers, P.J., Burger, C.W.

"Recurrence rate in vulvar carcinoma in relation to pathological margin

distance." Int J Gynecol Cancer 20.5 (2010): 869-73.

26. Tatarchuk, T., Yefimenko, 0., Zanko, 0., Schavinskaya, M.

"Comparison of ultrasound investigation methods in postmenopause."Georgian

Med News $283(2018)$ : 19-26.

27. Doll, K.M. Meng, K., Basch, E.M. etal.

"Gynecologic cancer outcomes in the elderly poor: A population-based study." Cancer 121.20 (2015): 3591-9.

\section{EXTERNAL GENITAL TUMORS IN WOMEN: ROLE OF DIFFERENTIATION, LOCALIZATION AND HISTOLOGICAL TYPES FOR PREDICTING LONG-TERM SURVIVAL VALUE}

0.0. Samokhvalova, gynecologist-oncologist, Research Department of Oncogynecology, National Cancer Institute, Kyiv

K.V. Kopchak, MD, leading researcher, Research Department of Abdominal Tumors, National Cancer Institute, Kyiv

Y.G. Tkalia, PhD, gynecologist-oncologist, Research Department of Oncogynecology, National Cancer Institute, Kyiv

V.S. Svintsitsky, MD, professor, scientific head of the Research Department of Oncogynecology, National Cancer Institute, Kyiv

Purpose of the study was to investigate the role of the tumor degree, localization and histological type of tumor at the level of long-term survival by 25 -year retrospective observation in women with external genitalia cancer. Materials and methods. 557 medical records of patients treated in National Cancer Institute have been analyzed during the period of 1993-2018 years. Impact of the differentiation degree, localization and histological type on the long-term survival value has been evaluated.

Results. It has been proved that the long-term survival value decreased by $27.3 \%$ during transition from high (G3) to intermediate (G2) tumor grade, by $10.8 \%$ during transition from intermediate (G2) to low (G1) tumor grade. The overall level of 25 -year survival retrospectively constituted $45.0 \%$ with $\mathrm{G} 3$ tumor grade, $31.0 \%$ with $\mathrm{G} 2$, and $26.0 \%$ with $\mathrm{G} 1$ tumor grade $(p<0.05)$.

The highest mortality has been demonstrated with total affection (66.7\%), as well as with lesions of several zones (80.9\%). The multiple Kaplan-Meier survival analysis showed that the most unfavorable localization was the area of labia minora, where the probability of survival at 25 -year-long observation was $6.0 \%$ versus $23.0 \%$ for the primary tumor localization in the area of labia majora, and versus $35.0 \%$ in the vulvar region localization.

Conclusion. The highest rates of cancer mortality are verified in non-differentiated forms of tumor (100.0\%) and for sarcoma (63.6\%) depending on the morphological form of primary tumor. Mortality rate was more than $50.0 \%$ for all forms of squamous cell cancer. Carcinoma and adenocarcinoma with a level of mortality by $20.6 \%$ and $21.4 \%$ respectively were more favorable compared to the other morphological forms.

Keywords: external genital tumors, survival value, differentiation degree, histological type.

\section{ПУХЛИНИ ЗОВНІШНІХ ГЕНІТАЛІЙ У ЖІНОК: РОЛЬ ДИФЕРЕНЦІАЦІІ,, ЛОКАЛІЗАЦІЇ ТА ГІСТОЛОГІЧНИХ ТИПІВ У ПРОГНОЗУВАННІ РІВНЯ ТРИВАЛОГО ВИЖИВАННЯ}

0.0. Самохвалова, лікар гінеколог-онколог науково-дослідного відділення онкогінекології НІР, м. Київ

К.В. Копчак, д. мед. н, провідний науковий співробітник науково-дослідного відділення пухлин органів черевної порожнини НІР, м. Київ

Ю.Г. Ткаля, К. мед. Н., лікар гінеколог-онколог науково-дослідного відділення онкогінекологї̈ НІР, М. Київ

В.С. Свінціцький, д. мед. н., професор, керівник науково-дослідного відділення онкогінекології НІР, м. Київ

Метою дослідження було вивчення ролі ступеня пухлини, ї̈ локалізації та гістологічного типу на рівні тривалого виживання шляхом 25-річного ретроспективного спостереження жінок із раком зовнішніх статевих органів.

Матеріали та методи. Проаналізовано 557 історій хвороб паціенток за період 1993-2018рр., які лікувались на базі Національного інституту раку. Проведено оцінку впливу ступеня диференціювання, локалізації та

гістологічного типу на рівень віддаленої летальності.

Результати. Доведено, що при переході від високого до помірного ступеня диференціювання смертність зростала на 27,3\%, при переході від помірного до низького ступеня диференціювання - на 10,8\%. Загальний рівень 25-річної виживаності при ретроспективному спостереженні становив 45,0\% при високому ступені диференціювання пухлини, 31,0\% - при помірному, 26,0\% - при низькому ступені диференціювання (р < $0,05)$.

Під час оцінювання прогностичного значення локалізації первинної пухлини найвищу смертність доведено при тотальному ураженні (66,7\%), а також при ураженні кількох ділянок (80,9\%). При множинному аналіз виживаності за методом Каплана-Мейера найбільш несприятливою локалізацією була ділянка малих статевих губ, де вірогідність виживаності при 25-річному ретроспективному спостереженні досягала 6,0\% проти 23,0\% при локалізації первинної пухлини в ділянці великих статевих губ та 35,0\% при локалізації в ділянці вульви.

Висновки. Залежно від морфологічної форми первинної пухлини найвищі показники смертності верифіковані при недиференційованих формах пухлини (100,0\%) та при саркомі (63,6\%). При всіх формах плоскоклітинного раку смертність становила більше 50,0\%. Порівняно сприятливішими відносно інших морфологічних форм були карцинома та аденокарцинома 3 рівнем смертності відповідно 20,6\% та 21,4\%. Ключові слова: пухлини зовнішніх статевих органів, віддалена летальність, ступінь диференціювання, локалізація, гістологічний тип.

\section{ОПУХОЛИ НАРУЖНЫХ ГЕНИТАЛИЙ У ЖЕНЩИН: РОЛЬ ДИФФЕРЕНЦИАЦИИ, ЛОКАЛИЗАЦИИ И ГИСТОЛОГИЧЕСКИХ ТИПОВ В ПРОГНОЗИРОВАНИИ УРОВНЯ ДЛИТЕЛЬНОГО ВЫЖИВАНИЯ}

Е.А. Самохвалова, врач гинеколог-онколог научно-исследовательского отделения онкогинекологии НИР, г. Киев

К.В. Копчак, д. мед. Н., ведущий научный сотрудник научно-исследовательского отделения опухолей органов брюшной полости НИР, г. Киев

Ю.Г. Ткаля, К. мед. Н., врач гинеколог-онколог научно-исследовательского отделения онкогинекологии НИР, г. Киев

В.С. Свинцицкий, д. мед. Н., профессор, руководитель научно-исследовательского отделения онкогинекологии НИР, г. Киев

Целью исследования было изучение роли степени опухоли, ее локализации и гистологического типа на уровне длительного выживания путем 25 -летнего ретроспективного наблюдения женщин с раком наружных половых органов.

Материалы и методы. Проанализированы 557 историй болезней пациенток за период 1993-2018 гг., которые проходили лечение на базе Национального института рака. Проведена оценка зависимости отдаленной летальности от степени дифференцировки, локализации и гистологического типа опухоли.

Результаты. Доказано, что при переходе от высокой к умеренной степени дифференцировки общая смертность увеличивалась на 27,3\%, при переходе от умеренной к низкой степени дифференцировки - на 10,8\%. Общий уровень 25-летней выживаемости при ретроспективном наблюдении составил 45,0\% при высокой степени дифференцировки, 31,0\% - при умеренной, 26,0\% - при низкой степени дифференцировки (р < $0,05)$.

При оценке прогностического значения локализации первичной опухоли наиболее высокий уровень смертности наблюдался при тотальном поражении (66,7\%), а также поражении нескольких участков (80,9\%). При анализе выживаемости по методу Каплана-Мейера наиболее неблагоприятной локализацией был участок малых половых губ, где вероятность выживаемости при 25-летнем ретроспективном наблюдении достигала 6,0\% против 23,0\% при локализации первичной опухоли в области больших половых губ и 35,0\% при локализации в области вульвы.

Выводы. В зависимости от морфологической формы первичной опухоли наиболее высокие показатели смертности верифицированы при недифференцированных формах опухоли (100,0\%) и саркоме (63,6\%). При всех формах плоскоклеточного рака смертность составляла более 50,0\%. Сравнительно более благоприятными были карцинома и аденокарцинома с уровнем смертности соответственно 20,6\% и 21,4\%.

Ключевые слова: опухоли наружных половых органов, удаленная летальность, степень дифференцировки, локализация, гистологический тип. 